\title{
めっき排水規制対応に向けたファインバブル前処理技術
}

\author{
森久保 諭 ${ }^{\mathrm{a}}$, 田熊 保彦 ${ }^{\mathrm{a}}$, 西田 葵 ${ }^{\mathrm{a}}$, 榎本 大佑 ${ }^{\mathrm{a}}$, 小坂 幸夫 ${ }^{\mathrm{a}}$ \\ ${ }^{a}$ (地独) 東京都立産業技術研究センター ( ⿳ 135-0064 東京都江東区青海 2-4-10)
}

\section{Fine Bubble Pretreatment Technology for Compliance with Plating Wastewater Regulations}

Satoshi MORIKUBO a, Yasuhiko TAKUMA ${ }^{\text {a }}$, Aoi NISHIDA a , Daisuke ENOMOTO ${ }^{\text {a }}$ and Yukio KOSAKA a

${ }^{a}$ Department of Research and Development, Tokyo Metropolitan Industrial Technology Research Institute (2-4-10, Aomi, Koutou-ku, Tokyo 135-0064)

Keywords : Zinc Wastewater, Wastewater Treatment, Plating Chemicals, Effluent Regulation, Fine Bubble

\section{1. はじめに}

めつき事業所の排水中に含まれる多くの有害物質の排出は, 水質污濁防止法・下水道法によって厳しく規制されている。 規制対象物質のうち, 亜鉛の排水基準值は, 2006 年の法改 正で $5 \mathrm{mg} / \mathrm{L}$ から $2 \mathrm{mg} / \mathrm{L}$ へと強化されたが, 電気めっき業に おいては, 排水の組成が複雑で処理が困難であることから 2022 年 12 月 10 日まで暫定水質基準值 $(5 \mathrm{mg} / \mathrm{L})$ が設定され ている。しかしながら, 将来的には暫定基準值の見直しによ る規制值の強化が予想されることから, 亜鉛めっきを取り扱 うめっき事業所では, 本則の排水基準值に対応可能な排水処 理対策が必要となる ${ }^{1), 2)}$ 。

我々は，これまでに，東京都鍍金工業組合と連携した都内 めっき事業所への巡回指導の実施や排水規制に対応した亜鉛 処理技術の開発等, めっき業の排水規制対策に取り組んでき た ${ }^{2)}$ 。本稿では, 過去 5 年間に渡り実施してきた巡回指導に より明らかになった「亜鉛めっき事業所が抱える排水処理の 課題」へ対応するため, これまでに我々が取り組んできた 「ファインバブルを用いた前処理技術」について紹介する。

\section{2. 亜鉛めっき排水処理における課題}

\section{1 めっき事業所における亜鉛排水処理の課題}

我々は, 2015 年から東京都鍍金工業組合と共同で都内の めっき事業所への巡回指導を行い, これまでに延べ 49 社の 排水処理状況の調査を実施してきた。巡回指導の結果から亜 鉛排水処理の課題は, 大きく分類して, (1)排水処理槽におけ る $\mathrm{pH}$ 調整の不良, (2)フロック生成不良 (拡大不良)による固 液分離の悪化, (3めっき用薬品に含まれる錯形成剂と亜鉛と の錯体形成による再溶解 ${ }^{2)}$ の 3 つがあることが明らかになった。 一般的にめっき排水中の亜鉛は水酸化物沈殿法で処理を行 う。まず，中和槽で $\mathrm{pH}$ を $9.5-10.5$ に調整して水酸化覀鉛 を生成させ, その後, 凝集槽で凝集剂を添加し, 水酸化亜鉛 のフロックサイズを拡大させる。凝集槽で拡大させたフロッ クは, 沈殿槽にて沈降させ, 固液分離を行う（図 1)。しかし
ながら, (1)の $\mathrm{pH}$ 調整不良や(2)のフロックの生成不良が起こ ると, 水酸化亜鉛の凝集沈殿処理が不十分となり, 亜鉛の処 理不良が生じてしまう。(3)錯形成による亜鉛の再溶解につ いてもフロック生成不良の一種であるが, こちらは, 処理条 件や設備の不良というよりも排水中に混入している夾雑成分 の影響が大きい。いずれの課題も排水処理への影響は大きい が, (1)の $\mathrm{pH}$ の調整不良については, 原因がはっきりしてい るため対策方法は明確である。(2)については, フロックの状 態は, 処理薬品の添加量や凝集沈殿設備の不良が主な原因で あることから一部設備の更新が必要となる場合もあるが, 適 切な処理環境を確立することができれば，対応可能となる。 一方で, (3)の課題については, 含有される錯形成剤の種類に よっては, 処理が困難になることから, 適切な対策が必要と なる。図 1 に示したとおり, 悪鉛錯体は水溶性のため, 現場 での目視確認が難しく処理への影響が分かりにくいという問 題もある。

\section{2 めっき用薬品が排水処理に及ぼす影響}

めっき業で使用される脱脂剂やめっき浴, 光沢剂等の薬品 には様々な種類の錯形成剤が使用されており, 排水中には,

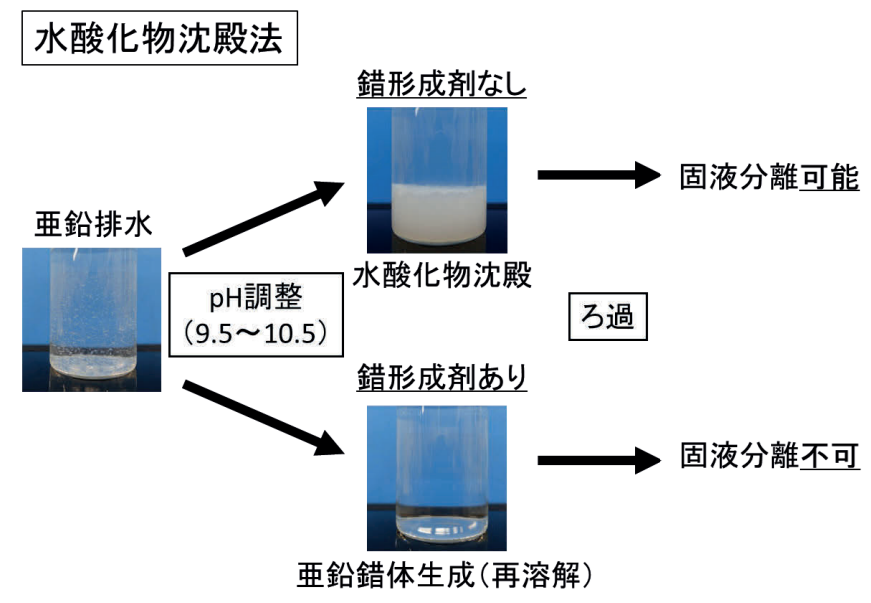

図 1 水酸化物沈殿法と錯形成剤の影響 
表 1 めっき用薬品に使用される錯形成剤と亜鉛処理不良目安濃度 ${ }^{2)}$

\begin{tabular}{c|c|c|c}
\hline 錯形成剤 & 化学式 & 使用例 & $\begin{array}{c}\text { 亜鉛処理不良 } \\
\text { 目安濃度 }[\mathrm{mg} / \mathrm{L}]\end{array}$ \\
\hline エチレンジアミン四酢酸二ナトリウム & $\mathrm{C}_{10} \mathrm{H}_{14} \mathrm{~N}_{2} \mathrm{O}_{8} \mathrm{Na}_{2}$ & 脱脂剤等 & 8.8 \\
\hline ピロリン酸ナトリウム & $\mathrm{Na}_{4} \mathrm{P}_{2} \mathrm{O}_{7}$ & 脱脂剤等 & 14 \\
\hline リン酸二水素カリウム (参考) & $\mathrm{KH}_{2} \mathrm{PO}_{4}$ & クロメート & 47 \\
\hline クエン酸三ナトリウム & $\mathrm{C}_{6} \mathrm{H}_{5} \mathrm{Na}_{3} \mathrm{O}_{7}$ & 脱脂剂等 & 97 \\
\hline トリエタノールアミン & $\mathrm{C}_{6} \mathrm{H}_{15} \mathrm{NO}_{3}$ & 電解脱脂 & 290 \\
\hline 塩化アンモニウム & $\mathrm{NH}_{4} \mathrm{Cl}$ & めっき浴等 & 590 \\
\hline
\end{tabular}

その多くの物質が含有されている。前項で紹介した通り, 排 水中に錯形成剂が混入すると，西鉛の再溶解により，固液分 離作業が困難となる。また, めっき用薬品に含有されている 成分には，錯形成剂以外にもフロックの凝集を妨害する物質 があることも示唆されており，これらは，固液分離作業を困 難とする原因になる。表 1 に我々が過去の研究で確認した めっき用薬品に含まれる代表的な亜鉛排水処理妨害物質の種 類と影響の大きさを示す ${ }^{2)}$ 。表 1 のとおり，妨害物質の種類 によって排水処理に及ぼす影響は異なるが，多くの化合物が 亜鉛排水処理を阻害することが分かる。

妨害物質の一つであるアンモニアについては, アンモニア ストリッピング法, 不連続点塩素処理法, 生物学的硝化脱窒 法等の除去方法が知られている ${ }^{3)}$ 。我々は, アンモニアスト リッピング法及び不連続点塩素処理法のめっき排水中のアン モニア除去への適用可能性を検討し, これらの方法によりア ンモニアを除去できること，そして除去により排水処理への 影響を低減できることを示した ${ }^{4)}$ 。一方，特に影響が大きい 脱脂剤由来の成分については, EDTA 等のように一度混入す ると処理が困難になるものが多い。アンモニア以外の錯形成 凰の対策については，pH を酸性にすることで，錯体を分解 する方法 ${ }^{5), 6)}$ や鉄塩やカルシウム塩を加えることで錯形成し た亜鉛イオンを置換し，遊離した亜鉛を沈殿させる置換法 ${ }^{5), 7)}$ 等が検討されているが，一つの方法で全ての妨害物質に対応 することは困難であり，コスト面やスラッジ排出量の増加等 の課題がある。亜鉛排水規制対応のためには, 強力な錯形成 剂を含む脱脂剂の排水中への混入を防ぐことが重要となる。 そこで, 我々は, 脱脂剤の使用量を削減する技術として様々 な特性を持つ微細気泡であるファインバブルに着目した。

\section{3. 洗浄工程へのファインバブル技術の適用}

\section{1 ファインバブルの性質と前処理洗浄工程への適用}

直径 $100 \mu \mathrm{m}$ 以下の微細気泡であるファインバブル $(\mathrm{FB})$ は, 気泡サイズによってマイクロバブル $(1 \sim 100 \mu \mathrm{m})$, ウルトラ ファインバブル $\left(1 \mu \mathrm{m}\right.$ 以下) と定義されている(図 2) ${ }^{8)}$ 。 FB は, 気体 (空気, 窒素等) と水から成るにも関わらず, 通常の水や 気泡と比べて高い疎水性相互作用や浸透効果, 表面電荷作用 等様々な性質を示すことが知られており ${ }^{8), 9)}$, 近年, 農業や 医療，工業等幅広い分野での応用が進められている。また， FB の疎水性相互作用や表面電荷作用による洗浄効果につい ても注目されている ${ }^{10)}$ 。そこで我々の研究では, めっき前 処理洗浄工程への FB 洗浄技術の適用を検討し, 脱脂剂の使 用量削減を目指した前処理洗浄技術の開発を行った。また,

\section{ファインバブル(FB) : 直径 $100 \mu \mathrm{m}$ 以下の気泡の総称 \\ マイクロパブル ウルトラファインパブル<smiles>C1CCCCCC1</smiles>

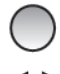 \\ 直径: $1 \sim 100 \mu \mathrm{m}$

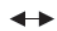 \\ 直径: $1 \mu \mathrm{m}$ 以下 \\ 特異な性質 - 疎水性相互作用 ·表面電荷特性 ·高浸透性等}

\section{農業や医療、工業等幅広い分野へ応用}

図 2 ファインバブルの定義 ${ }^{8)}$

脱脂剂使用時と FB 使用時の亜鉛の排水処理性の違いを確認 することで，排水処理性の向上効果についても検討を行った。

\section{2 ファインバブルによる洗浄効果}

めっき前処理洗浄工程を想定し，油を付着させた金属を用 いて FBによる洗浄効果の検討を行った。金属には，鉄製の ボルト $(\mathrm{M} 10 \times 30 \mathrm{~mm})$ およびプレート $(1.0 \times 25 \times 50 \mathrm{~mm})$ を用 いた。これらの金属を油に浸したあと, 遠心分離機 $(2500 \mathrm{rpm})$ で，1 分間余剰の油をとばしたものを実験用サンプルとした。 なお，付着させる油には，基油(鉱物油)を用いた。また， FB は加圧溶解式の FB 発生装置 (株式会社シンワ製, プログ レス 750)を用いて発生させた。約 $20 \mathrm{~L}$ の純水が入った水槽 に FB を発生させ, そこに攪拌機の先端に固定した油付着サ ンプルを入れ，15 分間擋拌洗浄を行った。

FB 洗浄前後の油の付着状態を紫外線照射によって確認し た写真を図 3 に示す。白く見える部分が油の付着部位である。 図 3 に示したとおり，FB 洗浄によって金属表面に付着した 油が除去されていることが分かった。洗浄前後の重量変化か ら油の除去率を確認した結果では, ボルトで約 $73 \%$, プレー トで約 $77 \%$ と比較的高い洗浄効果を示した。比較で用いた 2 種類のアルカリ脱脂荗による洗浄の結果では, 油の除去率 は 40〜90\%であったことから，FB 洗浄でも脱脂剤と同等の 洗浄効果がみられ, 脱脂剤の種類によっては, 同等以上の洗 浄効果があることが分かった。一方で, サンプルの形状や部 位によって洗浄効果にばらつきがみられた。単純形状のプ レートでは比較的広い範囲に油が残るのに対して, ボルトで は複雑形状のねじ部に油が残留しやすいことが確認された。

以上の結果から, FB 洗浄が金属表面に付着した油の洗浄 に効果的であることが確認され，FB 洗浄のめっき前処理工 程への適用可能性が示唆された。一方で, 金属の形状によっ ては効果に差が出ることも分かった。また，本研究では検討 していない油種類, FB 発生条件等, 様々な要因が洗浄効果 


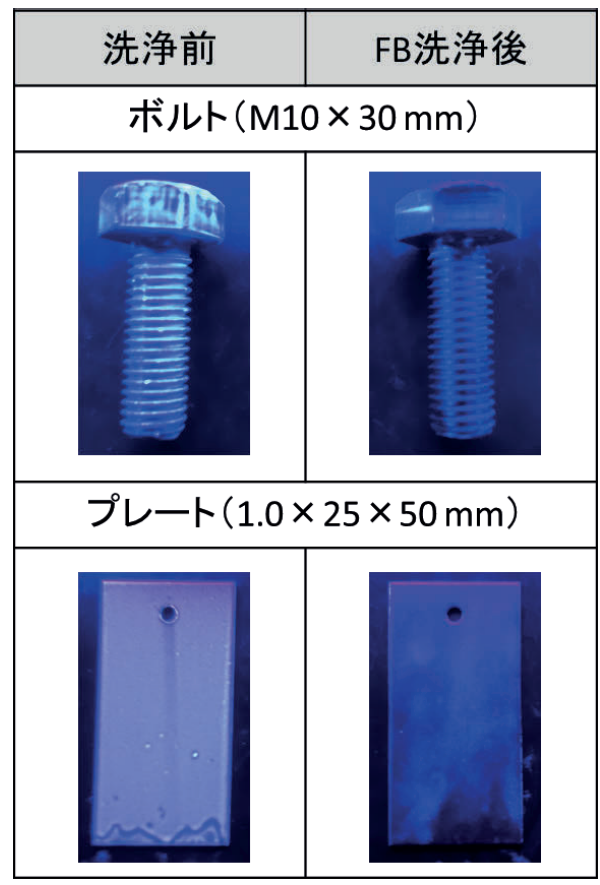

図 3 ファインバブルによる油の洗浄効果

に寄与すると想定されることから, 洗浄条件やサンプル条件 等の更なる検討は実用化に向けて重要な課題であるといえる。

\section{3 ファインバブルによる排水処理性の向上}

FB 洗浄に油の除去効果があることが確認されたが, FB 水 が排水に混入することで，亜鉛排水処理を阻害してしまうと めっき前処理洗浄工程への適用は困難となる。そこで, FB 洗浄水が带鉛排水処理に及ぼす影響を確認するため, 塩化亜 鉛を超純水に溶解させた模擬排水 (含有亜鉛濃度約 $100 \mathrm{mg} / \mathrm{L}$ ) に FB 洗浄水を $1 \%$ の割合で加えたサンプルを調製し，排水 処理後の残留亜鉛濃度の分析を行った。排水処理は水酸化物 沈殿法により, 亜鉛を沈殿させた後, 孔径 $0.45 \mu \mathrm{m}$ のメンブ レンフィルターで溶液をろ過する方法で実施した。また，残 留亜鉛濃度の分析には，ICP-OES を用いた。さらに，排水処 理効果の比較のため, アルカリ脱脂剂を $1 \%$ の割合で加えた サンプルにおいても同様の実験を行った。

FB 洗浄液が带鉛排水処理に及ぼす影響を調べた結果を図 4 に示す。図から分かるように, FB 洗浄水を $1 \%$ の割合で混 合したサンプルでは, 残留亜鉛濃度が $0.3 \mathrm{mg} / \mathrm{L}$ となり, 本 則基準值 $2 \mathrm{mg} / \mathrm{L}$ 未満という非常に良好な处理結果となった。 一方で，アルカリ脱脂剂 $(\mathrm{A}, \mathrm{B})$ をそれぞれ $1 \%$ の割合で混 合したサンプルの処理結果では, どちらも残留亜鉛濃度が高 い值となり, 暫定基準值 $5 \mathrm{mg} / \mathrm{L}$ を大幅に超過することが分 かった。以上の結果から, FB 洗浄水は, 亜鉛排水処理に影 響を及ぼすことはなく，非常に有効な技術であることが確認 された。

\section{4. おわりに}

めっき業の亜鉛排水規制対応を目指した技術として FB 用いた前処理洗浄技術について簡単に紹介した。本稿で示し たと扔り, FB 洗浄は, 特定の条件下扔いては, アルカリ脱 脂剂と同程度の洗浄効果があることが分かった。一方で，サ

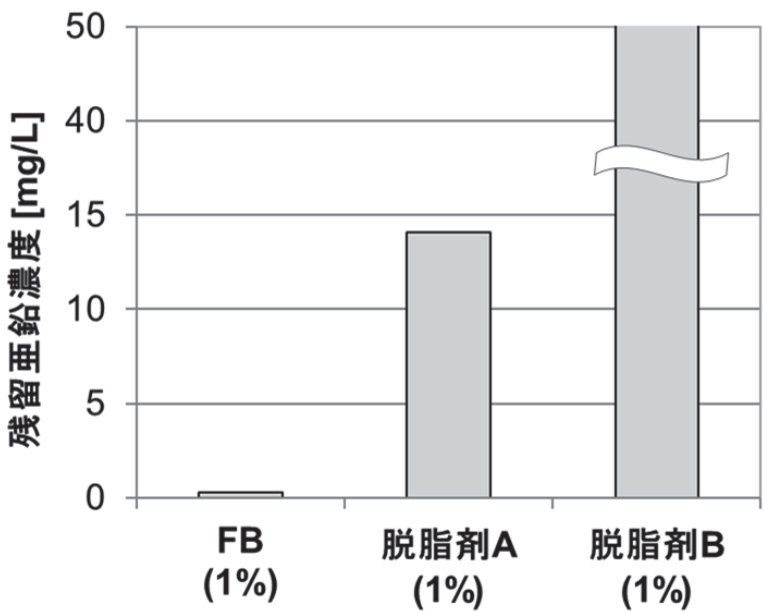

図4 ファインバブル水が亜鉛排水処理に及ぼす影響

ンプルの形状によって洗浄効果に違いがでることも確認され た。FB 洗浄を実用化するためには, 今後油の種類や付着状況, 洗浄条件等を含めた検討が必要となると考えている。また, 排水処理性の確認を行った実験の結果から, FB 洗浄水は, 排水処理に影響を及ぼさないことが確認された。亜鉛をはじ めとするめっき排水処理を実施する上で，めっき用薬品によ る排水処理の阻害は大きな問題となることから, 脱脂剂削減 につながる可能性を見出すことができたのは有用な結果であ ると考えられる。現時点で, FB 洗浄を脱脂剂の代替技術と するには検討すべき項目がまだ複数存在するが，完全に代替 できなくても，部分的に FB 洗浄を導入することができれば， 脱脂剂使用量の削減につながり, 結果的に排水処理の課題解 決へとつながると考えられる。今後は，めっき事業所との共 同研究を行い, 実際の現場での検討を進めながら, 実用化に つなげていきたいと考えている。

\section{謝 辞}

本研究の一部は, 平成 29 年度荒川区地域産業活性化研究 補助金，一般財団法人内藤泰春科学技術振興財団 2019 年度 調査・研究開発助成の支援を受けたものです。この場を借り て深く御礼申し上げます。

(Received September 4, 2020)

\section{文献}

1 ) J. Inamoto ; J. Surf. Finish. Soc. Jpn., 65, 515 (2014).

2 ) S. Morikubo, Y. Takuma, A. Nishida, Y. Kosaka ; J. Surf. Finish. Soc. Jpn., 69, 527 (2018).

3 ) M. Nonomura ; Jitsumu Hyomen Gijutsu, 29, 428 (1982).

4 ) S. Morikubo, Y. Takuma, D. Enomoto, Y. Kosaka ; Abst. 135th Meet., p. 226 (Surf. Finish. Soc. Jpn., 2017).

5 ) Y. Kosaka ; Hyomen Gijutsu, 48, 242 (1997).

6 ) H. Wada ; J. Surf. Finish. Soc. Jpn., 65, 504 (2014).

7 ）北川幹夫；省エネと環境に配慮した産業排水処理, p. 178 (日本 工業新聞社, 2013)。

8 ) A. Yabe ; Jpn. J. Multiphase Flow, 30, 45 (2016).

9 ) 寺坂宏一; 化学工学, 78, (9), 580 (2014).

10) T. Hata, Y. Nishiuchi, M. Sakamoto ; J. Surf. Finish. Soc. Jpn., 68, 317 (2017). 